\title{
Research on the Influence Factors of Chinese Local Government Debt Scale
}

\author{
Kun $\mathrm{Li}^{1, \mathrm{a}}$ \\ ${ }^{1}$ School of International Trade and Economics, University of International Business and Economics, \\ Beijing 100029, China; \\ asulan_kunli@outlook.com
}

Keywords: Government debt scale; GDP; Influence factor

\begin{abstract}
Recent years, the problems of local government debt have been widely discussed by many researchers, moderate scale of local government debt is very essential to economic growth. Based on the analysis of local government debt scale research, this paper analyzes the influence factors of Chinese local government debt scale through regression model which shows debt scale is positively correlated with gross domestic product and local urban population proportion, negatively related with the government fiscal surplus.
\end{abstract}

\section{Introduction}

Recent years, the local government investment and financing platform has played an important role in the process of tackling the international financial crisis and promoting local economic growth. However, as the important tool to balance the budget of local government at every levels, the local government debt can be a "double-edged sword". On one hand, moderate scale of local government debt can not only promote the local investment and economic growth, but also can broaden the financing channels, accelerate the construction of social infrastructure, improve the level of public service, and promote urbanization process[1]. On the other hand, if the debt scale of local governments exceeds the moderate scale it will cause a certain degree of debt risk which will harm the sustainable development of local economy, also can affect the normal operation of local finance and social stability.

In response to the global financial crisis, a lot of countries in the world have adopted a proactive fiscal and looser monetary policy to promote its economy out of the trough. In china, under the active fiscal policy and appropriately loose monetary policy, the investment and financing platforms have become effective tools for local governments to complete the money issued tasks and complete the target of economic growth. According to the national government debt audit results the national audit office announced in 2013, the Chinese local government debt under the provincial level has come to more than 18 trillion yuan, and has the trend of expansion. The local government debt scale of China has raised a lot of attention both form the government and researchers, study on the influence factors of local government debt scale can help to reduce financial risks and promote the sustainable development of economy in China.

\section{The development of local government debt scale research}

With the expansion of the government debt scale, government debt can promote social and economic development and also caused the financial crisis at the same time. Therefore, domestic and foreign scholars began to study on the moderate government debt scale control.

Greiner and Semmler introduced the productive public capital variables to the output function in order to build the indefinite frontier model to study the moderate government debt scale in different finance budget system[1]. Chalk chose the government budget constraint, the enterprise profit maximization and consumer utility maximization as an index of objects, built the alternation of generations model to empirical analysis on sample in order to discuss the biggest deficit the deficit finance sustainable under the condition of equilibrium[2]. Under hypothesis conditions of in fiscal 
policy aiming at certain fiscal deficit and monetary policy aiming at a certain rate of inflation, by building the overlapping generations model, Thadden researched the relations of indebtedness, economic growth, and the deficit and inflation rate under the equilibrium state of settlement of currency, settlement of government debt, physical capital[3]. Through the study of the Japanese economy in the $1990 \mathrm{~s}$, Barseghyan thought the continuous expansion of Japanese government debt scale caused the capital loss, offset the capital marginal product increment, eventually lead to the trend of declining of interest rate[4].

According to the literatures about Chinese local government debt scale research, based on the analysis of various economic variables that could affect the government debt scale, Lv and Cui Using the measurement method to test the relationship between debt scale and different variables, they think the fluctuations in gross domestic product (GDP), the balance of the debt, the fiscal revenue and expenditure and the deficit levels are the main factors that influence the government debt scale[5]. A lot of researchers use the methods of measurement (variance decomposition, Granger causality test, unit root test and impulse response function, etc.) to build regression models to analyze the influence factors of the size of government debt. Credit, savings, debt issuance, gross domestic product (GDP), debt lurch higher debt and budget deficits have been analyzed as the mainly factors influence the Chinese local government debt scale.

\section{The empirical analysis of the influence factors of local debt scale}

The hypothesis. In this research, because the scale of local government contingent liabilities and stealth debt in China, used the total amount of local government debt which is the sum of the debt government is liable for repayment, the debt government is liable for guarantee, the debt government may be liable for rescue as the dependent variable. According the literatures review, the independent variables can be summarized as follows:

(1) Local economic gross domestic product (GDP): the regional financial policy is related to the corresponding economic growth targets, regional economic growth will ease people's tolerance and expectations of government liabilities. In the meantime, the growth of economy will make the market more active and the spending of local enterprises and institutions will bring more contingent liabilities to the government. Therefore, the local economy gross government and the debt scale are positively related.

(2) Local government fiscal surplus(gov_surplus): if the fiscal revenue of local government is sufficient, there is no necessary to finance with debt. Therefore, the local government fiscal surplus and the debt scale maybe negatively related.

(3) Total investment on local fixed assets(investment): the total investment on fixed assets can represent a regional demand for investment. In general, a large part of government spending will be used on investment and infrastructure. The local investment demand will lead to the local government investment, the bigger investment demand is, the bigger debt scales the government like to borrow. Therefore, the total investment on local fixed assets and the debt scale maybe positively related.

(4) Urban population proportion (urban ratio): As a control variable to regional basis development level control, with the expansion of local urban population, the corresponding fiscal policy and spending will increase. On the other side, a big proportion of urban population can also a sign of a relatively complete local infrastructure which means the spending is relatively small.

Data collection and descriptive statistical analysis. In China, the local debt audit began at year 2011, and been promoted at the whole country at 2012. In this research, the debt audit data from 2012 and 2013 is collected, which contains the relevant data of 29 provinces and municipalities (not included Hong Kong, Macao and Taiwan regions). Because Tibet was not involved in the local debt audit in 2012 and the data missing in Guizhou province, so the samples do not contain those twos provinces.

The data of the local economic gross domestic product, the government fiscal surplus, the total investment on local fixed assets, and the urban population proportion all come from the national statistics yearbook of China. The data of total local government debt come from the audit results 
published by the provincial audit office. Used the year 2012 as the base period, eliminate the effects of price changes.

According to the structure of collected data, the total sample observations is 58, contains two periods and 29 individuals. The sample characteristics are collected in table 1.

Table 1 Sample characteristics

\begin{tabular}{ccccccc}
\hline & $\begin{array}{c}\text { Sample } \\
\text { Number }\end{array}$ & Mean & $\begin{array}{c}\text { Standard } \\
\text { Deviation }\end{array}$ & Maximum & Minimum & $\begin{array}{c}\text { Diffusion } \\
\text { Coefficient }\end{array}$ \\
\hline $\begin{array}{c}\text { total amount of local } \\
\text { government debt }\end{array}$ & 58 & 5398.84 & 2772.38 & 14430.00 & 723.25 & 0.51 \\
GDP & 58 & $\begin{array}{c}20246.1 \\
4\end{array}$ & 14584.55 & 60668.51 & 1893.54 & 0.72 \\
investment & 58 & $\begin{array}{c}13506.3 \\
7\end{array}$ & 8229.019 & 35986.66 & 1883.422 & 0.61 \\
urban_ratio & 58 & $\begin{array}{c}55.5788 \\
2\end{array}$ & 12.76711 & 89.6 & 38.75 & 0.23 \\
gov_surplus & 58 & -1554.88 & 738.5783 & -370.37 & -3342.95 & -0.48 \\
\hline
\end{tabular}

The scatter diagrams of the independent variables are in figure 1, as it shows in the scatter diagram of GDP, the total amount of government debt present obvious positive correlation with GDP. The total amount of government debt also present positive correlation with investment. While the total amount of government debt and government fiscal surplus did not show obvious linear correlation.

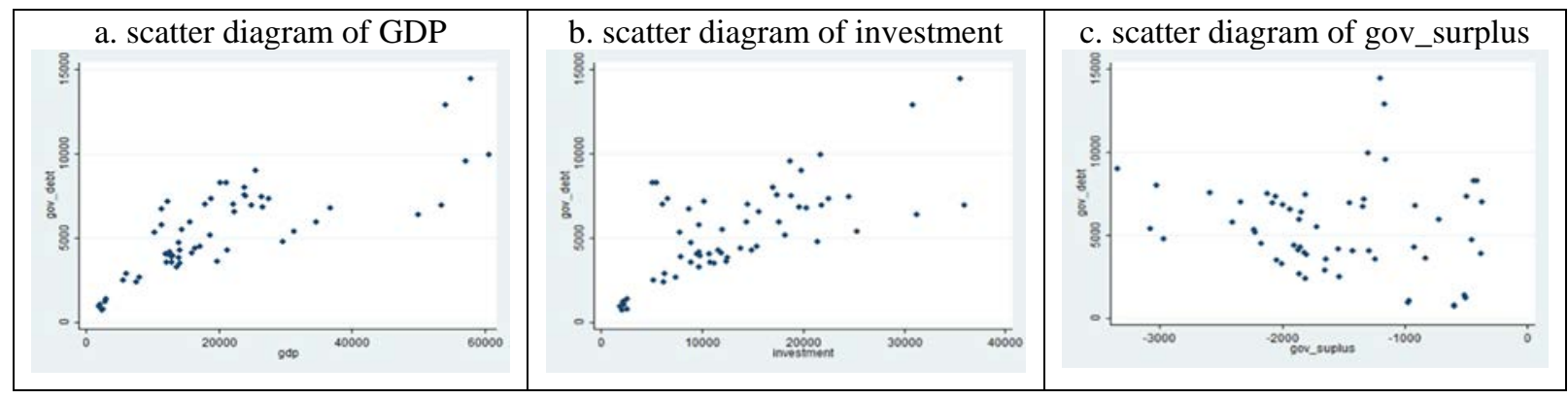

Fig. 1 Scatter diagrams

The regression analysis of the influence factors. The regression analysis of the influence factors is in table 2. Regressions are OLS regressions where the dependent variable is the total amount of local government debt, observations are from the audit results published by the provincial audit office from 2012 to 2013.

According to the regression 1 and regression 3, whether contains the urban_ratio or not, the relationship between GDP and government debt scale is significantly positive correlation. In the regression 2, the relationship between government fiscal surplus and government debt scale is not significant. In regression 4, the VIF is 4.62, while VIF of investment and GDP are 6.96 and 6.38 respectively, and the correlation coefficient between the two variables is 0.87 . Therefore, the regression 4 exist the multiple collinearity problem.

Regression 5 and regression 6 take logarithm of GDP, compared with regression 1 and regression 3 , though the logarithm of GDP also has significant positive relationship with debt scale, but the Adjusted R2 has no obvious difference, and the other independent variables are not significant related. Therefore, it is better to choose the linear form of GDP. Regression 7 and regression 8 are the cubic regression of the government fiscal surplus, whether join the other variables or not, the separate and joint inspection are not significant. 
Table 2 Regression analysis of the influence factors

\begin{tabular}{|c|c|c|c|c|c|c|c|c|}
\hline & (1) & (2) & (3) & (4) & (5) & (6) & (7) & (8) \\
\hline \multirow{2}{*}{ GDP } & $0.15^{* *}$ & & $0.12^{* *}$ & $0.11^{* *}$ & & & & $0.11^{* *}$ \\
\hline & $(0.02)$ & & $(0.03)$ & $(0.02)$ & & & & $(0.03)$ \\
\hline \multirow{2}{*}{$\ln (G D P)$} & & & & & $2756.32^{* *}$ & $\underset{*}{2588.904}{ }^{*}$ & & \\
\hline & & & & & (283.32) & $(565.50)$ & & \\
\hline \multirow{2}{*}{ gov_surplus } & & -0.59 & $-1.39^{* *}$ & $-1.35^{* *}$ & & -0.13 & -5.13 & -6.12 \\
\hline & & $(0.45)$ & $(0.43)$ & $(0.56)$ & & $(0.75)$ & (7.31) & $(4.07)$ \\
\hline \multirow{2}{*}{ gov_surplus $^{2}$} & & & & & & & -0.003 & -0.002 \\
\hline & & & & & & & $(0.005)$ & $(0.003)$ \\
\hline \multirow[b]{2}{*}{ gov_surplus $^{3}$} & & & & & & & $-6.82 e-07$ & $-4.93 e-07$ \\
\hline & & & & & & & $\begin{array}{c}(8.06 \mathrm{e}-07 \\
)\end{array}$ & (4.6e-07) \\
\hline \multirow{2}{*}{ urban_ratio } & & & $98.52^{* *}$ & $99.31^{* *}$ & & 36.95 & & $113.90^{* *}$ \\
\hline & & & (21.05) & (19.90) & & (34.52) & & (25.55) \\
\hline \multirow{2}{*}{ investment } & & & & 0.02 & & & & \\
\hline & & & & $(0.07)$ & & & & \\
\hline \multirow{2}{*}{ nodal increment } & $2307.14^{*}$ & $4473.76^{*}$ & $-4685.21^{*}$ & $-4718.3^{*}$ & $-21162.09^{*}$ & $-21518.9^{* *}$ & 2973.97 & -7578.44 \\
\hline & (397.53) & $(940.05)$ & (1374.02) & (1332.3) & (2613.58) & $(2807.44)$ & (3040.6) & $(2747.31)$ \\
\hline gov_surplus $^{2}$,gov_surplus ${ }^{3}=$ & & & & & & & $\begin{array}{c}1.28 \\
(0.2859)\end{array}$ & $\begin{array}{c}0.66 \\
(0.5226)\end{array}$ \\
\hline \multirow{2}{*}{ coefficient $=0$} & $52.15^{* *}$ & 1.75 & $64.01^{* *}$ & $50.99^{* *}$ & $94.65^{* *}$ & $59.02^{* *}$ & $3.07^{*}$ & $39.69^{* *}$ \\
\hline & $(<0.001)$ & $(0.1910)$ & $(<0.001)$ & $(<0.001)$ & $(<0.001)$ & $(<0.001)$ & $(0.0356)$ & $(<0.001)$ \\
\hline Adjusted $\mathrm{R}^{2}$ & 0.64 & 0.01 & 0.72 & 0.71 & 0.68 & 0.68 & -0.01 & 0.72 \\
\hline SER & 1695.18 & 2810.58 & 1521.92 & 1549.70 & 1605.63 & 1615.61 & 2886.51 & 1560.63 \\
\hline
\end{tabular}

According to the analysis above, regression 3 is the satisfactory regression results.

$$
\begin{aligned}
& \text { gov_debt }=-4685.21+0.12 \mathrm{GDP}-1.39 \text { gov_su rplus }+98.52 \text { urban_ratio, } \overline{\mathrm{R}}^{2}=0.72, \mathrm{SER}=1521.92 \\
& \begin{array}{llll}
(1374.02) & (0.03) & (0.43) & (21.05)
\end{array}
\end{aligned}
$$

The local government debt scale is positively correlated with gross domestic product and local urban population proportion, negatively related with the government fiscal surplus.

Table 3 the regression of the influence factors of debt scale

\begin{tabular}{ccccccc}
\hline & GDP & gov_surplus & urban_ratio & $\begin{array}{c}\text { nodal } \\
\text { increment }\end{array}$ & GDP & gov_surplus \\
\hline $\mathrm{t}$ & 4.59 & -3.23 & 4.68 & -3.41 & $\mathrm{t}$ & 4.59 \\
$\mathrm{p}$ & $<0.001$ & 0.002 & $<0.001$ & 0.001 & $\mathrm{p}$ & $<0.001$ \\
$\begin{array}{c}\text { 95\%confidence } \\
\text { interval }\end{array}$ & $(0.0680663$, & $(-2.254782$, & $(56.30791$, & $(-7439.946$, & $95 \%$ confidence & $(0.0680663$, \\
\hline
\end{tabular}

\section{Summary}

The local government debt scale is positively correlated with local gross domestic product. The local economic gross $\$ 100$ million per change will bring changes of 12 million yuan of total local government debt. Economic growth will make all kinds of local enterprises and institutions become 
relatively frequent to trading, and some of them will tend to expand debt for investment or other spending. Part of the liabilities will become the government's contingent or recessive debt which leads to the high level of government debt. The local government debt scale is negatively correlated with local government fiscal surpluses. The local government fiscal surpluses $\$ 100$ million per change will lead to changes of -139 million yuan in government debt. When government fiscal surplus is sufficient, there is no need to gain the government debt scale. The local government debt scale is positively correlated with the urban population proportion. Every 1\% change of urban population proportion will lead to changes of 9.85 billion yuan in government debt. However, the relationship between debt scale and those influence factors can be further analyzed with the consideration of fixed effect and time effect. While the national policy, the national fiscal and taxation system, etc., will also affect local government debt scale.

\section{References}

[1] Greiner, A. and W. Semmler, Endogenous growth, government debt and budgetary regimes, Journal of Macroeconomics, 2000. 22(3): p. 363-384.

[2] Chalk, N.A., The sustainability of bond-financed deficits: An overlapping generations approach. Journal of Monetary Economics, 2000. 45(2): p. 293-328.

[3] von Thadden, L., Active monetary policy, passive fiscal policy and the value of public debt: Some further monetarist arithmetic. Journal of Macroeconomics, 2004. 26(2): p. 223-251.

[4] Barseghyan, L., Crowding out and the rate of return on capital in Japan. Japan and the World Economy, 2006. 18(3): p. 278-297.

[5] Lv Bingyang, Cui Xingfang, The Analysis of Effect of the Economic Factors on National Debt Issuing. Collected Essays on Finance and Economics, 2005(5): p. 58-62. 